\title{
Rising Toll of Frauds in Banking: A Threat for the Indian Economy
}

\author{
Neha Sharma \\ School of Management Studies, Punjabi University, Patiala (Punjab) \\ Dhiraj Sharma \\ School of Management Studies, Punjabi University, Patiala (Punjab)
}

\begin{abstract}
Banking is a process which predicts the relationship between sources of funds and their application. The basic process of banking helps the society to bridge the gap between availability and usage of these available funds in a correct manner. Over the years the banks have developed in a very big way, and with the growth of banking business, banking frauds have taken birth. The history of banking frauds is almost as old as the banking startup. Today, bank frauds have taken all possible forms and are prevalent in every facet of banking. There is a spirited need for banks to always stay alive to threat of frauds, build strong systems that can shield, pre-empt frauds, continuously monitor and review the efficiency of such preventive systems. To succeed in controlling frauds, banks need to be proactive and pre-emptive. This study establishes a theoretical framework with regards to banking frauds in the Indian context as well as shows the picture of frauds in banking sector outside India. By reviewing various studies in the area of banking frauds the paper built a research model which further helps to find out various types of frauds and reasons for the same, and will definitely give new scope to further studies. The present study sheds light on the area by reviewing various studies in the field of banking frauds. The study helps to find out the growth and trends of frauds in the banking sector and specially focuses on Indian Banking sector, as at present there are very few studies which give an in-depth insight of frauds in banking sector. Further the study also reviews the role of employee and customer with regard to banking fraud studied which is primarily needed in the context of Indian Banking system. The present study is conducted by collecting secondary data from the published and unpublished Sources, Government Publications, journals, magazines, books and periodicals etc.
\end{abstract}

Key Words: Banks, Frauds, Cyber Frauds, Prevention Techniques, Bank Employee Loyalty, Customer Satisfaction.

\section{INTRODUCTION}

Banking is a process by which banks bridge the gap between the sources of funds and their application. The term banking means "the accepting, for the purpose of lending or investment, of deposits of money from public, repayable on demand or otherwise and withdrawal by cheque, draft, or otherwise" (Banking Regulation Act, 1949). The concept of banking as we know it today originated in India long back in the late decades of $18^{\text {th }}$ century. As per central banking committee 1931 (RBI 2008), moneylenders started this concept of accepting deposits and issuing receipts for the same in India. However the banking activities were discovered long back in the Vedic period i.e. 2000 to

Journal of Technology Management for Growing Economies Vol. 9, No. 1 April, 2018 pp. $71-88$

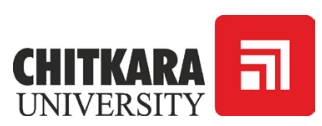

(C)2018 by Chitkara University. All Rights Reserved. 
Sharma, N.

Sharma, D.
1400 BC. Even the traces of professional banking have been found in Kautilya Arthashastra in $400 \mathrm{BC}$ where the terms such as lenders, creditors, and lending rates were used.

The primary and traditional functions and objectives of banks are to accept money from depositors and offer loans to the borrowers and also facilitate payments as a part of the country's payment and settlement systems. In their starting years in India, Banks provided basic intermediary services of sourcing funds in the form of deposits and diverting them towards productive sectors of the economy. But overtime, as the economy developed and moved from a production led growth phase to consumption led growth phase, the credit demand from the basic industrial and infrastructure sectors got lessened and banks started to lend to masses to cater to their consumption requirements. Easier access to loans meant that more consumers could buy more products and services and benefited from 'buy now' and 'pay later' concept.

\section{Frauds in Banking Sector}

Over the years the banks have developed in a very big way, and with the growth of banking business, banking frauds have taken birth. The history of banking frauds is almost as old as the banking startup. The term fraud is defined as, "any behavior by which one person intends to gain a dishonest advantage over another" (RBI, 2013).

Thus Reserve bank of India defines fraud as an act of commission and / or abetment, which is intended to cause illicit gain to one person(s), entity and wrongful loss to the other, either by way of concealment of facts by deceit or by playing a confidence trick.

Today, bank frauds have taken all possible forms and are prevalent in every facet of banking. There is a spirited need for banks to always stay alive to threat of frauds, build strong systems that can shield, pre-empt frauds, continuously monitor and review the efficiency of such preventive systems. To succeed in controlling frauds, banks need to be proactive and pre-emptive. Frauds in banks take place, when either the safeguards or procedural checks are inadequate or not adhered to, leaving the system vulnerable to perpetrators, who can be an insider or an outsider. A fraudster plans to strike the system at its most vulnerable point. An effective defense the bank can have against fraud is to continuously strengthen its operational practices, procedures, and control and review mechanism that fraud prone areas are sanitized against internal and external breaches.

The advent of computerization in banks have added a new dimension to the concept of frauds and the potential for fraud has brought about a need for a review and adaptation of a comprehensive control system aimed at fraud prevention.

Journal of Technology Management for Growing Economies, Volume 9, Number 1, April 2018 


\section{Nature and Types of Frauds in Banking Sector}

Frauds in banking sector can be classified as systematic or human failures, or a combination of both. Frauds arising out of both system and human failures in banks are grouped in the following four categories:

i. Frauds committed by bank employees.

ii. Frauds committed by bank employees, in collaboration of third party.

iii. Frauds committed by outsiders with insider support/ involvement.

iv. Frauds committed by customers or any other third party.

And the broad categories under which the above kinds of associations are formed to commit fraud takes place are as under:

a) Frauds related to advances

b) Cyber frauds or any other technology related frauds

c) Other frauds- $\mathrm{KYC} /$ deposit frauds, cheque frauds, accounting frauds, etc.

According to a survey on Indian Banking Fraud (Deloitte, 2015), 93\% of the respondents were of the view that the frauds in Indian banking industry have increased in last two years drastically. And the most frequent reasons for the increase in frauds were:

Negligence by the employees (including managerial level) in following the general processes.

Pressure on the employees for meeting the targets.

Lack of facilities for the identification of red flags.

Illegal cooperation between employees and outsiders.

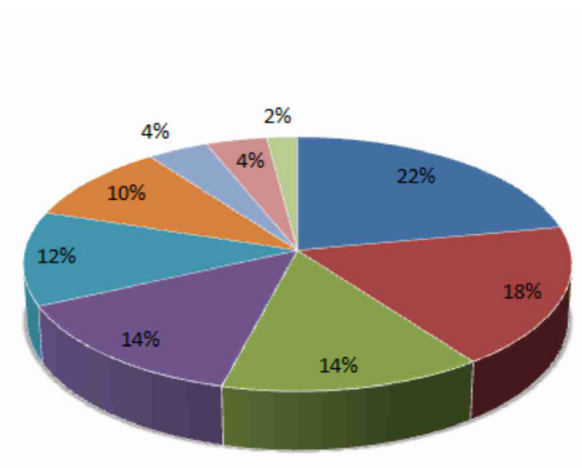

Rising Toll of Frauds in Banking

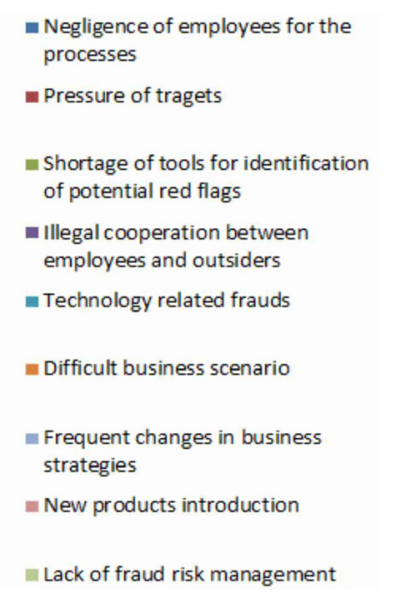

Chart 1: Major Contributors in Bank Frauds in India

Source: Indian Banking Survey, April 2015 (www.deloitte.com/in) 
Sharma, N.

Sharma, D.

The survey report highlighted the common frauds observed as:

(i) In Retail Banking sector: fraudulent documentation and overvaluation or absence of collateral.

(ii) In Corporate banking sector: diversion of frauds and siphoning of funds. (iii)In Private banking sector: identity theft and fraudulent documentation.

Also it was found that these frauds were discovered through the various sources like, by complaints by the customers, internal whistle blower and auditor's report and with the help of data analysis or by software's for transaction monitoring.

In yet another survey conducted by Deloitte (2017), it was found that about $65 \%$ of the respondents think that the trend of fraud is likely to increase in upcoming years. The main reasons responsible for occurrence of frauds are ineffective control, technological advancements and the support of unethical practices among employees. The top most frauds which are faced by the industry are bribery and corruption, financial statement fraud and embezzlement of funds.

\section{OBJECTIVES OF THE STUDY:}

The specific objectives of the present study is to examine the various fraud scenario in the context of Banking Industry as a whole including Indian banking industry as well as the banking industry situated in other countries too.

\section{SCOPE OF THE PRESENT STUDY}

Scope of the present study is confined to the banking industry and will analyze the frauds in the banking industry as a whole. For the same purpose the researcher have applied the method of content analysis, review of previous studies in the area of frauds in banking industry has been done. Apart from this some latest news reports of Indian newspapers have been gathered and discussed here for specifically knowing the present scenario of fraud in Indian Banking industry has been analyzed.

\section{RESEARCH GAP \& RATIONALE OF THE STUDY}

From a vast pool of studies in relation to banking frauds, it has been noticed by the researcher that the studies with detailed literature review are very few and especially in the Indian context the review study is almost in nil figures. So it is clear from the review of related studies in the area of banking frauds that there is a need of detailed research based on review and assessment in the area of banking frauds with particular focus on banking sector in India.

Journal of Technology Management for Growing Economies, Volume 9, Number 1, April 2018 


\section{REVIEW OF RELATED STUDIES IN THE AREA OF BANKING} FRAUD

\section{Studies for Frauds as a Concept in Banking Sector}

The term fraud has been explained by Association of Certified Examiners in the USA as the "use of one's occupation for personal enrichment through deliberate misuse or misapplication of employing organizations resources and assets". Khanna \& Arora (2009) discussed in their study the issue of frauds in banking industries. They evaluated the reasons responsible for frauds and banking sector. The study also discussed various fraud prevention methods taken by bank staff. The study was based on the primary data collected from the bank employees from the banks situated in India. Total 36 banks were covered including 253 respondents who were bank employees. The study revealed the perception of bank employees for preventive measures taken for banking frauds and also the importance of employees training program in bank fraud prevention was highlighted. The study indicated the results that there is lack of employee trainings, work pressure on staff, competition in the market and low adherence level for the RBI policies issued for prevention of frauds, as the main causes for banking frauds and the author suggested that there should be a strict measures to be taken for following the compliance and they should ensure the bank should follow anti fraud mechanism. However Chiezey \& Onu (2013) reviewed the presence of fraudulent practices in Nigerian banks. The study was based on the secondary data collected from the 14 Commercial Banks of Nigeria and Nigerian Deposit Insurance Corporation. It evaluated the effect of fraud and fraudulent practices occurred within a period of 10 years in Nigerian banking sector. The research evaluated different types of frauds and reasons responsible for that in Nigerian banking industry within the period of study.

Talking about Indian banking industry Bhatia (2013) reviewed the categories of frauds exists in Indian banking sector. The study discussed the common frauds that takes place in a bank generally such as saving account frauds related to deposits, cheque or demand draft related frauds, bills related frauds, loan \& hypothecation related frauds. Further the study reviewed various reasons for their happening in different banking sectors like in retail baking the reasons specified in the study were forged documentation, wrong sanctioning of credit, identified theft etc. whereas in corporate banking the major reasons were over valuation of securities, siphoning of funds and pressurized targeted jobs etc. Also the study suggested the respective preventive techniques for these frauds. It was a conceptual study based on secondary data collected from various banking website such as RBI, IBA etc. In the same way Bhasin
Rising Toll

of Frauds in

Banking 
Sharma, N.

Sharma, D.
(2015) explored the growth of frauds in the Indian Banking sector. The study was based on the primary as well as secondary data. The primary study was conducted by collecting the data from 345 bank employees specifically from the National Capital Region (NCR). The bank employees were asked for their experiences related to their own job training by the banks, awareness of the process prescribed by RBI, their own awareness level with regard to frauds and the policy of bank and RBI regarding compliance followance. The study showed the result as the $60 \%$ of the fraud cases occurred due to the reason like there was very limited rotation of responsibilities of employees, fake and false documentation had been increased drastically and less control over the account management. Further the findings showed that near $45 \%$ of the total frauds cases were committed by the managerial level employees. However, Singh et al. (2016) focused on the issue of increasing debts on banks and frauds occurring due to this issue. The study concluded with a detailed analysis in which the present scenario of Indian banking sector showed an ugly picture. The big players involved in the high misconduct of finances and the huge increase in NPA's in the Indian Commercial Banks over the past decades. The study showed that there is a quantitative as well as qualitative difference between the NPA's in Public Sector Banks and Private Sector Banks. The amount involved as compared to the number of cases in case of public sector Banks is huge as against the private sector banks in India. The major share was of credit related frauds in the total percent of frauds occurred in banking industry. The main reason highlighted for these credit frauds was negligence on the part of higher management, also the involvement of employees was found where they had collaboration with third party or in some cases they were found guilty alone which ultimately leads to the weak internal control mainly in the public sector banks.

\section{Studies for Frauds in connection with Employees}

Employees play a very significant role in the occurrence of fraud whether it is by employees or with the involvement of third party. Cressey (1973) strongly emphasized one of the factor of fraud occurrence in banks is trust in employees. The research was conducted based on the primary data collected on the basis of analytical induction. According to the author an employee who is facing any financial problem at his personal end can be a potential reason for increase in frauds. If there is some information, which is of confidential nature and by leakage of that information an employee can get some financial benefit then he can violate the trust. So it was concluded that greed of employee can be major reason for happening of frauds. However Bologna (1994) discussed the various external factors involved for occurrence of frauds. They were lack

Journal of Technology Management for Growing Economies, Volume 9, Number 1, April 2018 
of appreciation to employees, improper internal controls, non clarification of duties and responsibilities as well as the reporting area, the performance of the employees below expectation level, lack of reviews on time, audit and lack of proper follow-up for compliance for policies, goal attainment and government regulations. The study focused on the major reasons responsible especially to the embezzlement activities happening at branch level banking. The author found that the environmental factors were involved for these kinds of frauds. Further the study suggested the various prevention techniques that can be used for the prevention of these types of frauds. Whereas Kiragu et al (2015) discussed the occupational fraud at commercial banks situated in Kenya. The study indicated that the same had been increased on a wider scale. The researcher assessed the relationship of the size of commercial banks with the frauds committed by employees in these commercial banks in Kenya. The study chose all the 43 commercial banks operating in Kenya. A sample of 258 respondents was collected by using stratified sampling technique in the different bank branches of different commercial banks. The analysis was done by using different statistical tools like regression, ANOVA etc. It was found in the study that a negative and significant relationship exists between the size of bank and the in job frauds committed by bank employees. The study concluded that the in job fraud committed by bank employees were more in smaller banks than in the medium and large commercial banks in Kenya.

In a study conducted by Hillison et al. (1999), it was discussed that frauds committed by employees depends on the employee's personal situation and work pressure. The cited reasons were any financial credits or losses on personal ends, societal pressure and low satisfaction from the current job due to high pressure, can raise the situation of fraud committed by employees at work place. It was stated in the study that $95 \%$ of the total reviewed cases were due to the financial difficulties at the personal end of the fraudsters. It was found that the pressure on fraudster either job pressure or social pressure can push them to do the fraud. On the other front Kingsley (2012) highlighted the various reasons responsible for happening of frauds in Nigerian banking sector. According to the survey, the author listed some of the reasons as financial obligations on individuals, work pressure on employees, unsecured jobs, complicated legal formalities, high poverty ratio, maintenance of social life, wrong commitment by the managers and rigid competition in banking sector. It was suggested in the study that if the above parameters would not be taken care of then it can affect the profitability and liquidity of banks. However Sharma and Brahma (2000) focused on the banking fraud occurred due to banker's negligence. The study discussed the different kinds of frauds faced in routine banking operations like frauds related to cheques, hypothecation

Journal of Technology Management for Growing Economies, Volume 9, Number 1, April 2018
Rising Toll

of Frauds in

Banking 
Sharma, N.

Sharma, D. or loan. Saving bank accounts frauds bill related frauds foreign exchange transaction fraud and inter branch account frauds. The study was based on the secondary data, which was collected from the sources like RBI, IBA etc. It was found that the major reason for occurrence of these frauds is negligence of managerial officials. It was quoted in the study that RBI has already setup the safeguards for investigation of frauds by officials. The investigating agency of RBI helps to find out the actual cause of bank frauds and give their recommendations for prevention of such frauds. Further, it was suggested in the study that the immediate need for controlling these types of frauds is not an investigating agency of RBI but the managers and the handling bank staff should control it at branch level.

\section{Studies for Frauds due to Internal Management Control}

Every bank has its own systems and policies which should be made by following the protocols issued by central bank of a country, but when these systems have some gaps then it gives a chance to fraudsters to take benefit of the situation. In the same context Wolfe and Hermerson (2004) propounded the theory of fraud diamond. The theory discussed that the personalities, attitude, capabilities and abilities can play a significant role in determination whether fraud will occur or not. There could be many loop holes in the system but only the fraudsters who have the capability to identify the loop holes can get attracted towards that opportunity to do the fraud. The study presented a new model for the fraud occurrence and suggested the respective measures that can help in prevention of frauds. Pan et al. (2011) focused on the complex structure of financial markets, which can create opportunities for fraudsters. The study provided a conceptual framework for study of frauds in financial sector. It emphasized the usage of fraud triangle due to which the numbers of frauds have been increased. One of the major reasons for occurrence of frauds is the complex and innovative face of financial markets. Further the researchers tried to bring a model that how an individual, firm or an organization statistics motivates the occurrence of frauds in the organization. The study recommended that the individual traits and characteristics should be explored to know about the fraud and fraudsters.

A study conducted in Singapore by Willson (2006) depicts the causes responsible for crimes in baring banks. The study was based on a case undertaken in the banks of Singapore. The author listed the areas lack of supervision by management improper assignment of duties between the staff, lack of compliance following and low control on banking activities. The evidences of failure in the case study as no proper control of management on routine working, roles of back office staff and front office staff were not

Journal of Technology Management for Growing Economies, Volume 9, Number 1, April 2018 
specified properly and compliance and laws were not seriously adhered. Further he suggested the compliance of the banking laws and the causes should be taken seriously. Talking about Indian banking context Ghosh (1992) reported in a comprehensive report under the committee setup by RBI in the year 1992 to enquire the various types of wrong practices followed by Indian banks. Mr. A Ghosh headed the committee, the then Dy. Governor RBI. The committee found three major reasons contributing to frauds in banking sector which were leniency by the operating and the authorized staff, over confidence in the customers who were involved in frauds and the third party fraudsters who took the advantage of leniency in banking system. Also the committee suggested a uniform reporting system for all the banking sectors in India and it was held in the report that the classification of frauds should be followed as stated by Indian Penal Code of India. However Calderom and Green (1994) reviewed the real corporate fraud cases published in the internal auditor report between the periods of 1986-1990. The study was a conceptual framework based on the real cases happened in that specific time period. The analysis included 114 actual cases related to corporate frauds. It was found in the study that in $60 \%$ of the fraud cases there was cases of fraud documentation, improper controls and non specified duties of employees. Also the study reveals that in $45 \%$ of the involvement of managerial employees were there. Further the authors suggested the internal auditors play the major role to keep a good check on internal control system and preventing the frauds so every corporate should ensure efficient resources in their internal audit departments.

Vousinas (2016) examined the critical role of internal audit in the handling of bank frauds. The study took both the theoretical and empirical work already conducted by different researchers in the field and with the help of this literature he proposed a conceptual framework in which he had taken mainly four dimensions, namely Frauds, Risk (operational, legal \& reputational), Internal Audit (Anti fraud techniques, risk assessment \& loss prevention) and lastly the loss (economic \& goodwill). The study highlighted the various types of internal audit techniques in term of fraud prevention techniques and implementation of controls at every step in the banking sector. It also talked about the anti fraud methods to control the frauds in the industry and the data mining process in relation with bank frauds. The conclusion of the study clearly states that the internal audit is a very important dimension which can control the number of frauds in the banking sector and also it is the best tool for better management in any industry.

\section{Studies for Relationship of Frauds with Customer Satisfaction and Loyalty}

Customer is the base strength for any business and so as for banking sector, because it is only customer who gives basis for doing business but when there

Journal of Technology Management for Growing Economies, Volume 9, Number 1, April 2018
Rising Toll

of Frauds in

Banking 
Sharma, N.

Sharma, D. are incidences of trust breaking like fraud then it directly hit the satisfaction and loyalty part of customers. Hoffman \& Birnbrich (2012) created a conceptual framework for prevention of frauds, building customer relationships and customer loyalty. The study uses primary responses collected from the total 1491 respondents who were customers of a large German retail bank. The study was conducted to know the familiarity of customers towards the fraud management in their respective banks. Different variables were taken to conduct the study such as customer relationship with bank, customer satisfaction, trust among the customers and customer loyalty. The study concluded that there is a positive association between customer awareness regarding fraud prevention techniques and the level of customer satisfaction, trust and commitment. Also it was found that the level of customer relationship is positively correlated with customer loyalty in continuing their relationship with their bank. However Akelola (2014) investigated the various challenges faced by the banking sector in Kenya while controlling the frauds in the sector. Also the study analyzed the shortcomings for dealing with frauds by the public sector undertakings in Kenya. The study was based on the detailed field interview conducted with local 17 bank managers representing the different banks in Kenya. The findings of the study concluded that the most frequent reasons for happening of frauds in the various structural and institutional issues involved in the banking sector. Also the legal provisions were found inadequate in relation to fraud handling. Apart from this the study discussed some legal cases with regard to the bank frauds and also gave the legal implications and judgment reports in those specified cases. Further it was suggested that there should be a stronger legal policy for handling and preventing the fraud cases in the country.

\section{Studies for Frauds due to Technology}

One of the major concerns these days for banking sector is frauds related to technological flaw backs. Siddique \& Rehman (2013) presented a conceptual study which talks about various types of banking frauds such as money laundering, cyber frauds and other cards related frauds. The study reviewed the impact of cyber frauds on the present Indian banking scenario and various reasons responsible for electronic crime such as complex structure of the system, negligence at human part, loss of hard core evidence and data insecurity. They further suggested the preventive measures to control the cyber crimes as adoption of updated technology and appointment of trustworthy staff and other electronic devices. In the same way Bamrara et al (2013) reviewed various types of cyber attacks and the preventive strategies for facing these problems in India. The study was based on the primary data. The study took a sample of 100 cyber crime victims and 50 bank employees. It reviewed the strategies, which

Journal of Technology Management for Growing Economies, Volume 9, Number 1, April 2018 
were adopted by cyber fraudsters to target a particular bank and showed that the public and private sector banks are positively correlated in various kinds of cyber frauds. By using the statistical tools like Chi-Square and Karl Pearson's Coefficient of correlation the study depicted the relationships between the taken variables. It was found in the study that there was no significant difference between the strategies adopted in the cases of electronic frauds occurring in public and private sector banks. Further the study found that the intruder detection and cyber attacks were positively correlated. However Soni and Soni (2013) presented a comparative study of public sector and private sector banks in India for reviewing various cyber frauds. The study was based on the secondary data taken by published sources of reserve bank of India. It focused on two kinds of comparisons i.e. comparison of same sector banks and comparison of different sector banks. The data was analyzed for 27 public sector banks (including SBI and its associates, Cooperative banks), 14 private sector banks and 6 foreign sector banks. The analysis revealed the private and foreign sector banks have bigger share in frauds concerned with e-banking, debit and credit cards and other online banking transactions and the reason for happening of frauds was the introduction of technology in banking sector.

\section{Latest Fraud trends in Indian Banking Industry}

As per a case reported where a four member gang had been arrested by police authorities for committing fraud against Allahabad Bank amounting to Rs. 52 Lakhs. The accused presented the fake document and mutilated land documents. The bank manager registered a complaint to the police that the accused took a loan $\mathrm{f}$ Rs. 12 lakh on a 12 acre land and a loan of Rs. 20 lakh on a land of 30 acre. On the verification of land documents, it was found by the bank that those land documents were fake. And on this basis bank lodged a complaint against accused. On the arrest Police told that one of the accused was earlier working with a Patwari and he made the computerized fake documents there only (The Tribune: Mar, 2016).

In another case The State Bank of Patiala detected a huge fraud of around Rs. 5 Crore where the accused used the forged and fake documents, fake fard and forged revenue records for availing agricultural loans. After detecting the same the chief branch manager had been suspended for the same. The fraud came into light when it was realized that the total amount of disbursed agricultural loans were much higher than expected, and when the loan documents were matched with the records of Punjab Land Revenue Society (PLRS), they all were found to be fake. The internal audit committee discovered the fraud by checking it manually with the Patwaris (The Tribune: Jul, 2016).

Here in yet another case on the complaint of Syndicate bank, a complaint
Rising Toll

of Frauds in Banking 
Sharma, N.

Sharma, D. was lodged by the police. As per the report two ex- AGMs and former two chief managers of Udaipur and Jaipur branches of Syndicate bank, with the collaboration of a Chartered accountant, a builder and his two employees were involved in a fraud of Rs. 209 crore. Where, the accused availed a home loan by submitting the fake and fabricated documents. Then these funds were siphoned off to the companies owned by the accused. The police had registered the case under section 420 (cheating), $120 \mathrm{~B}$ (punishment of criminal conspiracy), 467, 468 (forgery for the purpose of cheating) and 471 (using as genuine a forged document) of IPC. However the master mind of the conspiracy was found to be the chartered Accountant (The Tribune: Mar, 2017).

As per RBI Data reports, ICICI Bank is on top rank in the bank fraud cases during the period April to December 2016. In this list the second ranked bank is State Bank of India. During the period of nine months it had been found that the most fraud cases were occurred in ICICI bank and the number of cases during this period was total 455 , which is closely followed by State bank of India figures with 429 cases. The third and forth rank in the list was taken by Standard Chartered Bank with 244 cases and HDFC Bank with 237 cases. Other banks who followed the trend were Axis Bank with 189 cases, bank of Baroda with 176 cases and CitiBank with 150 cases (The Economic Times: Mar, 2017).

However the volumes of fraud amounts showed that the SBI is on first rank with Rs. 2,236.81 Crore followed by Punjab National Bank with Rs. 2,250.34 Crore and Axis Bank with Rs. 1,998.49 Crore. The data provided by RBI to finance ministry revealed that in most fraud cases the involvement of bank staff was very evident. In SBI total 64 employees were involved in fraud cases, 49 bank employees were involved in HDFC fraud cases and 35 bank employees were found to be involved in Axis Bank fraud cases. The total figures showed that total 450 bank employees were involved from both Public and Private sector banks in total 3,870 fraud cases amounting Rs. 17,750.27 Crore (The Economic Times: Mar, 2017).

As per the report presented by one of the leading newspaper a case reported in the concern of demonetization where a manager of Kotak Mahindra Bank was arrested in a cheating and conversion case of around Rs. 35 Crore. The accused named Ashish Kumar was suspended by the bank authorities and was arrested by the police, even the special court had denied for his bail as he not only cheated the general public but government also. In the case the co-accused Raj Kumar Goel opened many accounts in different branches of different banks. As soon as the government announced the demonetization, they started to convert the currency on the fictitious names and fake accounts. They first deposited the amount in the fake accounts, and then issued the demand draft on the name of those fake

Journal of Technology Management for Growing Economies, Volume 9, Number 1, April 2018 
companies which they have created for opening the account. In total they converted Rs. 34.75 Crore. In this case the police had not recovered anything from the accused till now. And the court is still with the decision for not granting the bail to the accused as they did not only comply the RBI guidelines with regard to demonetization but they also had done a fraud with public and the government too (The Economic Times: May, 2017).

However in a case on the complaint of Zonal Manager of Punjab and Sind Bank, a couple has been booked by police for committing the crime with Punjab and Sind Bank. As per sources the accused Paramjit Kaur had taken a loan of Rs. 86 Lakhs one year ago for setting up of Kinnow Fruit grading and waxing plant. In the case her husband stood as a guarantor of the loan. Although at the time of site inspection no machinery was found by the officials. After this the officials file the case on the accused and Police have registered a case under sections 420, 406 and 120 B of IPC (The Tribune: Jul, 2017).

\section{RESEARCH HYPOTHESIS}

In the present research the following research hypothesis have been framed to fulfill the objectives of the study:

H1: There is no significant difference in the compliance level of employees as prescribed by RBI.

H2: Financial burden do not have significant relationship with the employee fraud. H3: Prevention techniques do not have significant role in fraud prevention.

\section{RESEARCH DESIGN}

The present study is descriptive in nature. The parameters of banking frauds are identified through the detailed literature review in the field. The critically reviewed literature of previously conducted study created a new scope for further studies. For this purpose of study data is collected from the published and unpublished reports collected from Public and Private Sector Banks under study, Reserve Bank of India, Indian Bank Association, Government Publications, journals, magazines, books and periodicals etc.

\section{TOOLS OF ANALYSIS}

The research method adopted for the present study is classical content analysis. The process of content analysis of earlier researches was adopted for the purpose of analysis. Moreover, review of similar work by the different researchers gave a deep intuitiveness to the present study which ultimately helped to conclude the study. The review of literature is a process, in the form of systematized body, explicit, and reproducible version of identification,

Journal of Technology Management for Growing Economies, Volume 9, Number 1, April 2018 
Sharma, N.

Sharma, D.

evaluation and synthesisation of the existing structure of work done by the eminent researchers in a particular field (Fink, 2010).

\section{THEORETICAL FRAMEWORK}

On the basis of the above literature review a framework can be drawn which would clear the significant factors of frauds in Banking sector and its actual results which is harming the industry as a whole. The main objective of this study is to present a conceptual model based on previous studies related to frauds in banking sector. Based on the review of literature and research problem, a theoretical framework has been developed and presented in Fig. 1 as shown below.

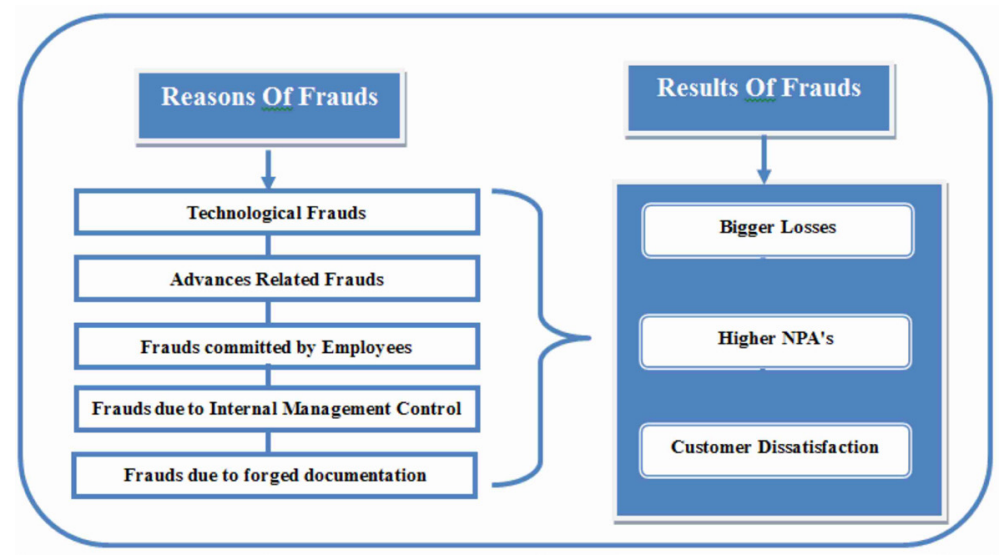

Figure 1: Research Model: Frauds in Banking Sector

\section{FINDINGS OF THE STUDY}

It is clear from the review of related studies in the area of banking frauds that fraud is not only a scenario which occur once, however, it is an incident which last long for a long time.

\section{Hypothesis Testing}

Table 1: Hypothesis Testing

\begin{tabular}{|l|l|l|l|}
\hline S.No. & Null Hypothesis & $\begin{array}{l}\text { Test } \\
\text { Statistics }\end{array}$ & Accept/ Reject \\
\hline H1 & $\begin{array}{l}\text { There is no significant difference in the } \\
\text { compliance level of employees as pre- } \\
\text { scribed by RBI. }\end{array}$ & $\begin{array}{l}\text { Content } \\
\text { Analysis }\end{array}$ & Rejected \\
\hline H2 & $\begin{array}{l}\text { Financial burden do not have significant } \\
\text { relationship with the employee fraud. }\end{array}$ & $\begin{array}{l}\text { Content } \\
\text { Analysis }\end{array}$ & Rejected \\
\hline
\end{tabular}

Journal of Technology Management for Growing Economies, Volume 9, Number 1, April 2018 


\begin{tabular}{|l|l|l|l|}
\hline H3 & $\begin{array}{l}\text { Prevention techniques do not have signifi- } \\
\text { cant role in fraud prevention. }\end{array}$ & $\begin{array}{l}\text { Content } \\
\text { Analysis }\end{array}$ & Rejected \\
\hline
\end{tabular}

In most of the studies the major factors in relation with frauds in banking sector which also proves the null hypothesis to be rejected were:

1.1 The banks are exposed to risks. This is especially because banks are easing account opening rules, thus overlooking the Know Your Customer (KYC) norms. Duplication of bank accounts, in the quest to achieve high targets or to avail insurance benefits, it is a big challenge. If duplicate accounts are opened but remain dormant, it would be financial inclusiveness only in name.

1.2 Yet another facility of overdraft could end up swelling bad loans for banks as the scheme does not spell out how the banks can collect debt waivers in the past, people may end up treating the loans as freebies.

1.3 Over burdening or lack of incentives of bank officials resulting in the hampering of normal operations, customer harassment etcetera also needs to be looked into. Most of the schemes that aim to cover the entire population have had their share of errors in on-boarding citizens information.

1.4 Many studies quote that the prevention methods play an important role in controlling the various frauds. The focus of the preventive vigilance activity is to create a right environment which would ensure the employees willingly complying with the systems and procedures, thus disallowing the damage to the interest of the organization, posed by the internal and external sources. Even though, the scope of preventive vigilance goes much beyond dealing with only fraud cases, the reality is that the frauds occupy a lot of time and efforts, and money of the organization, in terms of prevention, detection and appropriate follow-up measures. Fraud prevention is the most cost-effective way to minimize (if not to eliminate, into) the fraud incidents. There have been many studies conducted in the manufacturing sectors (which apply to service sector, in equal measure) which indicate that the cost of preventive maintenance vis-a-vis the corrective maintenance and the failure cost follows a ratio of 1:10:100. It indicates that the preventive measures do have a definite cost, but it is only 1 IlOth of the cost associated with correction related measures and only $1 / 100$ th of the cost if the actual failure takes place.

1.5 Prevent vigilance follows almost similar pattern vis-a-vis the other types of vigilance. Therefore it pays to have prevented vigilance culture in an organization then to "rue at one's leisure". A fraudster is actuated by personal gain motive for which, consciously or otherwise, he would do
Rising Toll of Frauds in Banking 
Sharma, N.

Sharma, D.

86

a mental risk-return trade-off. Once he reassures himself that the payoff for committing a fraud is higher than the associated risk-costs, he would try to take his chance. In this process, he sometimes twists the risk-return tradeoff, taking advantage of the environmental factors. This poses a real danger and sometimes it may not be possible for the fraud-buster to forecast / visualize the pattern of grand designs of the fraudster. However, more and more one shows willingness to know and learn about the possible loopholes and lacunae in the system, the probability of success of the fraudsters can be checked/ mitigated.

1.6 Once a fraud has been committed, there are no winners. Victims lose because of the stolen money, legal fees, lost time, public exposure, and other consequences. Perpetrators also lose because once caught, they suffer humiliation and embarrassment as also punishment. The investigation of fraud can be very expensive. Organizations and individuals that are associated with taking proactive fraud prevention measures usually find that these measures pay big dividends.

\section{CONCLUSION}

Fraud in recent times is a curse on banking industry and need an effective mechanism for fighting against frauds. From the review of above mentioned studies, it is clear that there are a very few studies which have been conducted in regard of banking frauds moreover the major work in this area are not concerned with the Indian banking Sector. Therefore the need for further research in the perspective of frauds in Indian banking industry has become imperative in the view of scarcity of research work in the area frauds in Indian banking sector which is still at its rudimentary stage in India. The detailed understanding and knowledge of frauds in Indian banking sector is highly valuable for government, bankers, academicians, auditors, bank customers and its stake holders.

\section{LIMITATIONS OF THE STUDY}

The present study is an ongoing research of Ph.D on the topic "Banking Frauds in India: Trends, Growth and Profitability Setbacks in Public and Private Sector Banks", so the present study has focused only on the review of literature part where the primary survey is a limit to this study. As this is only a review based study so many components like employee's perspective, customer's perspective and loss of banks through frauds had been skipped in the study.

\section{REFERENCES}

Serah, A. (2014) "Prosecuting Bank Fraud in Kenya: Challenges faced by the Banking Sector", Journal of Finance Management and Public Services, Volume 14, Issue. 1, p- 60- 78.

Journal of Technology Management for Growing Economies, Volume 9, Number 1, April 2018 
Anthala, H. R. (2014) "Research paper on Case laws of Fraud, forgery and Corruption in Banks and Financial Institutions in India", IOSR Journal of Economics and Finance, Volume 3, Issue 6. P 53-57.

Bamrara, A., Singh, G. \& Bhatt, M. (2013) "Cyber attacks and defense strategies in India- An Emperical assessment of Banking Sector”, International Journal of Cyber Criminology, Volume 7 issue. 1, p- 49- 61. http://dx.doi.org/10.2139/ssrn.2488413.

Banking Regulation Act (1949), available at www.cooperation.ap.gov.in/pdf/BR\%20Act\% 201949.pdf retrieved on 19.09.2015.

Bhasin, M. L. (2015) "Menace of Frauds in the Indian Banking Industry: An Empirical Study. Australian, Journal of business management and research, Volume 4, Issue 12, p- 1-13. http://dx.doi.org/10.2139/ssrn.2676466.

Bhatia, R. (2009) "Banking frauds-- a four billion rupees industry, accessed at accman.in/ gyanpj14/5.pdf.

Bhattacharjee, K. (2007) "Reverse Mortgage - A Novel Financial Product for Elderly People.

Bologna, J.G., (1994) "How to detect and prevent embezzlement? The White Paper, August/ September, $\mathrm{p} 4$.

Calderon, T. and Green, B.P. (1994), Internal fraud leaves its mark: here's how to spot, trace and prevent it”, National Public Accountant, Vol. 39, August, p. 17.

Chiezey, U. \& Onu Agbo J. C. (2013), Impact of Fraud and Fraudulent Practices on the Performance of Banks in Nigeria. British Journal of Arts and Social Sciences. Vol.15 No.1. p. $12-28$.

Cressey D. (1973), Others Peoples Money: A study in the Social Psychology of Embezzlement. Montclair, N. J. Patterson Smith

Deloitte, (2015), Indian banking fraud survey: Edition II. Retrieved on August 15, 2015 from http://www.deloitte.com.

Deloitte (2017), India Fraud Survey: Edition II. Retrieved on September 02, 2017 from http:// www.deloitte.com.

Fink, A., (2010), Conducting Research Literature Reviews, From the Internet to Paper, 3rd Edition, Los Angeles: Sage Publications

Francis Louise (2010), Banking on Robbery: The Role of Fraud in the Financial Crisis. Casualty Actuarial Society E-Forum, Fall 2010-Volume 2

Ghosh A (1992), RBI committee Report on Various aspects relating to fraud malpractice in Banks, pp. 4-10

Hoffmann Arvid O.I. \& Birnbrich Cornelia (2012), The impact of fraud prevention on bankcustomer relationships : An empirical investigation in retail banking. International Journal of Bank Marketing. Vol. 30 No. 5, p. 390- 407.

Indian Bank (2014), Fraud Risk Management Policy 2014- 15. Retrieved at www.aiiboa.in.

Indian Bank Association (2011), Evolution of Indian Banking Sector, Aranca Research, BMI. Retrieved at www.iba.org.in.

Khanna, A. and Arora, B. (2009) "A study to investigate the reasons for bank frauds and the implementation of preventive security controls in Indian banking industry", International Journal of Business Science and Applied Management, Vol. 4, Issue. 3. pp 1- 21.

Kingsley A. Adeyemo (2012), Frauds in Nigerian Banks: Nature, Deep-Seated Causes, Aftermaths and Probable Remedies. Mediterranean Journal of Social Sciences. Vol.3 Issue 2. P- 279- 289.

Kiragu, N. D., Gikiri. W. L \& Iminza, N.W (2015) "Bank size and occupational fraud risk: empirical evidence from commercial banks in Kenya", European Journal of Business Management, Vol. 2, Issue 1, p- 189-404.

Manikyam K. Ratna (2014) "Indian Banking Sector: Challenges and Opportunities", IOSR Journal of Business and Management, Vol. 16, Issue 2, Ver. 1, p- 52- 61.
Rising Toll

of Frauds in

Banking 
Sharma, N. Sharma, D.
Pan, G., Seow, P. S., Suwardy, T., \& Gay, E. (2011) "Fraud: A Review and Research Agenda. Journal of Accountancy Business and the Public Interest, Vol- 10, p- 138-178.

RBI(2008) "Evolution of banking in India, available at https://rbi.org.in/scripts/PublicationsView. aspx?id=10487.

RBI (2013) "Frauds in the Banking Sector: Causes, Concerns and Cures, available at https:// rbi.org.in/scripts/BS SpeechesView.aspx?Id=826

RBI (2014), Appropriation of Profit of Scheduled Commercial Banks, available at http://dbie. rbi.org.in/OpenDocument/opendoc/openDocument.jsp.

RBI (2015), Master circular-Frauds-Future approach towards monitoring of frauds in NBFCs, July 2015, retrieved at www.rbi.org.in.

Sharma, S. and Brahma (2000) "A Role of Insider in banking Fraud", available at http;// manuputra .com

Siddique M. Imran \& Rehman Sana (2011), Impact of Electronic crime in Indian Banking Sector-An Overview. Int. J Busi. Inf. Tech. Vol. 1, No.2, p-159-164.

Singh Charan et al. (2016), Frauds in the Indian Banking Industry, IIMB-WP N0. 505, pp. 1-24.

Soni R.R. and Soni Neena (2013) "An Investigative Study of Banking Cyber Frauds with Special Reference to Private and Public Sector Banks", Research Journal of Management Sciences. Vol. 2 Issue 7, p- 22-27.

The Economic Times: Mar (2017), ICICI Bank, SBI, StanChart top bank frauds list: RBI, Retrieved from: http://economictimes.indiatimes.com/industry/banking/finance/banking/ icici-bank-sbi-stanchart-top-bank-frauds-list-rbi/printarticle/57604612.cms

The Economic Times: May (2017), Demonetization fraud: Court denies bail to private bank manager, Retrieved from: http://economictimes.indiatimes.com/news/politics-and-nation/ demonetisation-fraud-court-denies-bail-to-private-bank-manager/printarticle/58824843. cms

The Tribune: Mar (2016), Four arrested for Rs 52-lakh fraud, retrieved from http://www. tribuneindia.com/news/punjab/crime/four-arrested-for-rs-52-lakh-fraud/213445.html.

The Tribune: Jul (2016), Fraud in farm loans detected at SBoP, Retrieved from: http://www. tribuneindia.com/news/jalandhar/fraud-in-farm-loans-detected-at-sbop/264714.html.

The Tribune: Mar (2017), Four ex-bank officials among 10 booked for Rs 209-cr fraud, Retrieved from : http://www.tribuneindia.com/news/nation/four-ex-bank-officials-among10-booked-for-rs-209-cr-fraud/382332.html.

The Tribune: Jul (2017), Couple booked for fraud, Retrieved from: http://www.tribuneindia. $\mathrm{com} /$ news/punjab/couple-booked-for-fraud/444187.html.

Vousinas Georgios L. (2016), The critical role of Internal Auditing in addressing bank fraud: A conceptual framework, Case Studies Journal ISSN (2305-509X) - Volume 5, Issue 3March-2016, Pp. 67-81.

Willson R. (2006), Understanding the offender/environment dynamics for computer crimes. Information Technology and people Vol. 19, Issue 2, p-170-186. 